\title{
Nuisance species: beyond the ecological perspective
}

\author{
Zina Skandrani ${ }^{1 *}$, Sébastien Lepetz ${ }^{2}$ and Anne-Caroline Prévot-Julliard ${ }^{1}$
}

\begin{abstract}
Introduction: 'Nuisance species' (or 'invasive' species) are often proposed to be the second most important concern in the context of the current biodiversity crisis. Despite increasing evidence that exotic species do not always become invasive, this perception is still common in the scientific community. This suggests that other issues are at stake in the concept of nuisance species rather than just the problems they raise, grounded mostly in ecological or economic arguments.

Methods: We retraced the evolution of pigeon representation in France through an extensive review of ancient texts related to pigeons and reviewed more than 240 source texts, dating from the seventh century to the 1990s. We completed these data with literature on human-animal relationships and animal conceptions in religious, philosophical, scientific, and political currents of thought that were representative of Western and, specifically, French tradition.

Results: We used the heated debate over pigeons (Columba livia) as pests as a case study by analyzing the ecological, social, economic, and political relations regarding pigeons. Through a historical perspective of the debate about and understanding of pigeons, we propose a new and complementary explanation for the modern thinking of pigeons as a nuisance species, based on what we termed their socio-nature characteristics. In particular, we used social representations theory to highlight the issues of human identity construction at stake in the construction of pigeons as a nuisance species.
\end{abstract}

Conclusions: We invite the reader to consider the impact of such human self-definition on environmental stances, as it could constrain further developments or improvements of conservation perspectives.

Keywords: Conservation; Human-animal relations; Identity construction; 'Nuisance species'; Social representations; Socio-natures

\section{Introduction}

'Nuisance species' (or 'invasive species' or 'alien species') are often proposed to be the second most important concern in the context of the current biodiversity crisis (Lowe et al. 2000; Wilcove et al. 1998) because they are a potential threat to native species through predation, grazing, competition, parasitism, disease, hybridization, or habitat alteration (Nunez et al. 2010; Elliott et al. 2010; Salo et al. 2006; Mooney et al. 2005; Pimentel et al. 2001). Since Elton (1958), the bias against alien species, which was expressed in their description as

\footnotetext{
* Correspondence: skandrani@mnhn.fr

'Centre d'Ecologie et des Sciences de la Conservation CESCO, UMR 7204

CNRS-MNHN-UPMC, Museum National d'Histoire Naturelle, CP 51, 55 rue Buffon, F-75005 Paris, France

Full list of author information is available at the end of the article
}

nuisances, has widely been embraced by the public, scientists, conservationists, land managers, and policymakers and has given birth in the 1990s to a discipline in its own right, 'invasion biology'. In biological conservation textbooks, invasive or nuisance species are described as more dangerous than environmental degradation, habitat fragmentation, and pollution because these may be more restrained and reversible than the reproduction and dispersal dynamics of nuisance species (for example, Primack et al. 2012). In addition to their potential devastating effects on natural ecosystems, nuisance species also have more general negative impacts on human beings. The IUCN, for instance, has proposed: 'They are causing significant damage to ecological, economic, and health levels. As a matter of fact, they can compete

\section{实 Springer}


with native species, act as pests or pathogens for cultivated or domesticated species, or even disseminate allergic or infectious agents.' (International Union for Conservation of Nature, 2013).

These generalized discourses about invasive species, however, have been increasingly debated and challenged in recent years (Marion 2013; Davis et al. 2011; Valéry et al. 2008; Warren 2007; Falk-Peterson et al. 2006; Colautti and MacIsaac 2004) than other causes of biodiversity loss (Stuart et al. 2004; Davis et al. 2011). Although some alien species can constitute real threats to native species or habitats, case-by-case studies are needed to explore their context-dependent impacts. Some species introduced by human beings are indeed destructive, for instance, zebra mussels (Dreissena polymorpha) in the Great Lakes, while in other places they can increase biodiversity (the honeysuckle, for instance, favors native bird species in Pennsylvania; Davis et al. 2011). It is also possible for native species to have similar devastating effects (Valéry et al. 2009). Because it is impossible to return to past ecosystems that have been increasingly transformed by a plethora of irreversible drivers of change (climate change, nitrogen eutrophication, increased urbanization, and other land-use changes), there has been an increased push to acknowledge 'novel ecosystems' (Chapin and Starfield 1997), which are composed of new combinations of species under new abiotic conditions. Therefore, many authors advocate for adaptive ecosystem management, focusing on the resilience of desirable states, rather than targeting the often-impossible eradication of undesirable species (for example, Seastedt et al. 2008).

Despite evidence that the nuisance status of some species has often been globally exaggerated, this 'bioxenophobia' (Marion 2013), which is based on the myth of stable and pure fauna or flora, persists. This suggests that more issues are at stake regarding the concept of nuisance species than the explicit ecological and environmental problems (Fazey et al. 2006; Wallace 2003). By widening our perspective, we can recognize that environments are combined constructions of physical, ecological, and social elements (Swyngedouw 1999). In this perspective, socio-physical constructions and environmental issues, such as nuisance species, are the consequences of interwoven socio-ecological processes (Heynen 2006). Following Swyngedouw (1999:445), 'natural or ecological conditions and processes do not operate separately from social processes, and [...] the actually existing socio-natural conditions are always the result of intricate transformations of pre-existing configurations that are themselves inherently natural and social.' (See also, Minteer and Collins 2005).

In this paper, we provide non-ecological evidence that advocates for the need to use caution when dealing with the alien species issue. We argue for a novel explanation of nuisance species as belonging to 'socio-natures' (see Swyngedowu 2004, 1999, Castree and Braun 2001) that, beyond de facto ecological considerations, are historically produced and continuously reformed by networks of human and non-human 'actants' (Latour 1993). 'In such a network of associations, each of the separate pieces is not independent, but is instead made to be the way it is by virtue of its relationship to all the other parts. [...] Nor is the identity of each actor independently formed and then joined to the whole. Instead, each becomes what it is through its specific relation to the other', (Robbins 2007:14).

We used the case study of the heated debate over feral pigeons (Columba livia), which are widely considered pests, to explore the socio-nature of nuisance species (Blechman 2006). We propose a new approach to this problem through the analysis of ecological, social, economic, and political relations, as well as power geometries, underlying this problem (Heynen 2006; Blaikie 1999). The case of the pigeon is particularly telling in this regard, as they have over history 'perhaps taken on more symbolic and functional roles than any other bird,' (Jerolmack 2008:74). Indeed, they originate from formerly domesticated pigeons that returned to a free state of living (that is, ferality). These were the first birds to be domesticated over 5,000 years ago, as their ancestors, wild rock doves, came to forage on cultivated fields in direct proximity to human beings (Johnston and Janiga 1995). Domestication created the white-colored pigeons that are famous in mythology, religions, and literature as 'doves'. Feral urban pigeons (which we shall refer to as urban pigeons) are found in all major cities around the world (del Hoyo et al. 2005) and are today the birds with the closest contact to people in cities; currently, these pigeons are mostly ascribed with a highly negative image (Vuorisalo et al. 2001).

Relying on an examination of the changing meaning of pigeons, we clarified, in some historical depth, what particular discourses and understandings of and about non-human beings are mobilized in the modern perception of pigeons as a nuisance species. Finally, we show that pigeons themselves have their own agency in shaping these (re)-configurations and hold an essential and active part in the system.

\section{Methods}

We retraced the evolution of pigeon representation in France through an extensive review of ancient texts related to pigeons in the following domains: religious, legal, economic, administrative, and literary, and in military reports, and treatises on zoology, agriculture, medicine, and cooking. We used texts available from the French numerical library Gallica from the Bibliothèque 
Nationale de France (2013), which provides access to over a million and a half documents, representative of the documents issued in France over the past centuries, that have been digitized by the Bibliothèque Nationale de France and other partner libraries. We searched for the French terms for pigeon (pigeon) and dove (colombe) and reviewed more than 240 source texts, dating from the seventh century (except for the Old Testament, which dates from the eighth to the second century BCE) to the 1990s. We narrowed the selection to 50 texts that reflected the variability of all the information and arguments. We selected these texts based on their pertinence to our subject, as a large part of the reviewed documents mentioned the words pigeon (pigeon) and dove (colombe) without providing any relevant information or providing repetitive material, such as the dove being a representation of the Holy Spirit.

To put pigeon representations into their historical frameworks, we completed these data with literature on human-animal relationships and animal conceptions in religious, philosophical, scientific, and political currents of thought that were representative of Western and, specifically, French tradition.

\section{Results}

Based on our historical search, we found a strong shift in the mid-twentieth century in the image of the pigeon, from a very positive historical representation to its current mostly negative image in mainstream public opinion.

\section{When pigeons were still gentle doves...}

In the religious realm, doves were often portrayed as animal companions to gods, such as the love goddess Kamadeva in Hinduism, and also as representations of gods themselves, as with Aphrodite and Venus, the goddesses of love in Ancient Greece and Rome (La Ville de Mirmont 1894). In Christianity, Christ received the Holy Spirit descending in the shape of a dove during his baptism (Raban Maur 842-847, in Voisenet 2000). In Islam, a pair of pigeons saved the prophet Mohamed's life by nesting in front of the cave he was hiding in and, in this way, misled his persecutors (Lings 1986).

Doves hold the role of divine messengers in various cultures. In Ancient Egypt, they uttered to oracles (Allys 1909, Bonnery 1909); in Ancient Rome, they constituted divine auguries (La Ville de Mirmont 1894); in the Old Testament story of Noah's Ark, they announced that the waters of the Flood had drained away by bringing back an olive branch from terra firma and thus announced God's forgiveness (Jerolmack 2007); and finally, in the Christian Hagiography they revealed to a pregnant mother the sanctity of her child by laying three drops of milk on her mouth, and afterwards the saint's impending martyrdom, through three drops of blood (Raban Maur
842-847, in Voisenet 2000). Consequently, the dove is the most cited animal within the Holy Scriptures (it is cited nearly 50 times) and illustrates Christian virtues, such as purity, simplicity of heart and soul, gentleness, and chastity (Voisenet 2000). These sacred representations largely influenced the famous symbol of the dove of peace and the literary figure of the romantic dove (La Fontaine 1678), that are still common in modern times.

The attribution of these symbolic charges to doves was related to the functions of pigeons in historical times. In medieval Christian logic, animals were symbolically separated into two opposite groups, representing good or Christ and the devil or Satan, to serve a moral purpose. These representations were supposed to help human beings situate themselves between vice and virtue and choose one of the two orders (Ribémont 1992). Birds, and among them doves, were used in this context as a pedagogical model to convey a spiritual message, encouraging human beings to behave better in life. Based on their faculty to move between the sky and the earth and to escape terrestrial confines, birds, and doves, established a connection between reality and the ideal, as well as the material and the spiritual. By linking them, they showed that conciliation between both was possible (Ribémont 1992). The wing symbolism was largely developed to exemplify the elevation of the human spirit and soul. It illustrated the progress dynamic and invited human beings to surpass themselves. Furthermore, because of their monogamous habits (Giunchi et al. 2007), doves also incarnated the ideal of the morally valued chastity and monogamy. Thus, doves became an instrument of the divine and were positively charged in support of the Christian quest for perfection and redemption (Voisenet, 2000).

However, in addition to this moral function, domestic pigeons also had different uses in everyday life. They were bred for their meat and for the use of their nitrogen-rich feces as fertilizer (Thiébaut de Berneaud 1841, Bourguignon 1882), to be used as messengers for communication purposes, and (although to a lesser extent) they were used for pleasure or sport (Johnston and Janiga 1995; de Planhol 2004). In the first French encyclopedias, which related the customs and representations of their time, pigeons were described as extremely profitable animals, and a special emphasis was placed on their value through the listing of their numerous uses and different breeds (Corneille 1694; Diderot and D'Alembert 1751; Lunel 1858).

Pigeon meat was, until the second half of the twentieth century, the second most eaten poultry and was mentioned just after chicken in cookbooks (Menon 1749; Foy 1845; Viard 1851; Courchamps 1853; Breteuil 1860) and treatises on agriculture (Rengade 1887; Brévans 1892; Favre 1905; Bonnier 1922). In France, the right to 
have dovecotes and keep pigeons was reserved for lords (De Ferriere 1741; Renauldon 1765) until the French Revolution in 1789. Pigeons were thus, in this context, an outward sign of nobility (Hoüard 1780; Henry 1981). After the abolition of this aristocratic privilege in 1789 (Gayot 1876; Rupin 1884), the breeding of pigeons was encouraged in the countryside and in cities as a means to provide families of the lower working class with meat and an additional financial resource until World War II (Bois 1847). Pigeon meat was indeed regularly cited in recipes in the gastronomic sections of journals during that period and in serial narrations of feasts. However, it appears from the sophisticated character of these menus that pigeon meat was still considered a delicacy and had maintained its former noble connotations inherited from its status under the Ancien Régime (Givois, unpublished data). The use of pigeon organs, blood, and feces or as a whole in popular medicine (Moquin-Tandon 1860; Spalikowski 1895; Reutter 1916; Hermant and Boomans 1928), contributed to this image of a precious and valuable animal.

The highest praise for pigeons was, however, expressed in the aftermath of the support they provided as messengers (they can be bred as carrier or homing pigeons) during various military conflicts. Pigeons were indeed already used for postal services in ancient times by Egyptians, Greeks, Romans, Hebrews, Persians, Chinese and Arabs, they were (re-)imported to early medieval Europe during the Crusades and in the context of commercial exchange (Van der Linden 1950). They were thus employed at the time of Caesar's conquest of Gaul to inform Rome of the progress of the invasion, during Hannibal's advancement through Europe (Jerolmack 2007) to announce the loss of the Battle of Waterloo to Napoleon I (Palliez 1932), or in a more civil context, to report earthquakes in Japan, to announce the return of ships of all nationalities into harbors (Gérardin 1905), and for communication between distant castles (Guidez 1969). In the nineteenth and twentieth centuries, messenger or soldier pigeons were used at an even larger scale during the Franco-Prussian War, and the liberation of besieged Paris in 1871 was only made possible through the exchange of thousands of messages and photographs carried by pigeons between Paris and London (Bulletin Technique du Génie Militaire 1936). Consequently, the breeding of homing pigeons was publicly advocated by political leaders and scientific experts. Despite the coming age of modern communication technologies, such as the telegraph and telephone, pigeons remained crucial during World Wars I and II to request munitions military support on the front lines and to inform about the progress of the enemy lines, as the other communication lines were easily destroyed and messages were intercepted or tapped (Gérardin 1905; Palliez 1932; Jerolmack 2007).
The ensuing allocation of public funding by the French government for pigeon fancier associations (Conseil Général. Rapports et Délibérations 1893, 1894, 1902, $1903,1926,1934)$ and the erection of monuments dedicated to pigeon soldiers in Lille (France) and Brussels (Belgium) confirm the extremely positive representation of pigeons during this period. At the same time, feeding street pigeons was such a common leisure pastime that urban parks had dedicated feeding sites and seed sellers.

\section{Pigeons (un)wanted: dead or alive}

This image is in sharp contrast with the current oftenexpressed dislike for pigeons. The progressive transformation of the representation of pigeons, from positive to negative, in the mid-twentieth century occurred contemporaneously with their unchecked proliferation in cities (Vuorisalo 2001), sanitary considerations, and the disappearance of historical uses for pigeons. The presence of pigeons in cities was already mentioned, anecdotally, in Nuremberg (Germany) in the twelfth century and in London (United Kingdom) in the fourteenth century (de Planhol 2004). In France, the pigeon was described in treatises and natural histories of pigeons at the end of the nineteenth century and at the beginning of the twentieth century as a free-ranging bird of domestic origins, living on farms and in the countryside (La Perre de Roo 1877; Barot 1891; Valette 1910). Pigeons were further counted among migrant species (Gayot 1876) and reported to be present only two or three times a year (Crespon 1844). From the mid-twentieth century on, pigeons moved towards urban areas and into human proximity. It is thus a consequence of a major change in pigeon ecology that they took over major Western cities. More precisely, the growth of urban pigeon populations through the colonization of a novel environment could be viewed as the result of an 'ecological fitting' (Agosta and Klemens 2008, 258 Janzen 1985) process, favored and triggered by various favorable factors: a large amount of food on city streets and marketplaces, numerous nesting sites in buildings, increased farming productivity with surpluses of grain (Johnston and Janiga 1995), and the high annual reproduction rate of the pigeons that had been selected during their former domestication. Important urban populations of pigeons developed all over Europe during this period (for example, in Hamburg, where the number grew from three nests in 1901 to 3,000 individuals in 1938 and 20,000 in 1963). In the 1960s, their numbers were estimated to be 100,000 in Munich (Germany), 60,000 in Turin (Italy), 200,000 in Vienna (Austria), and 8,000 to 10,000 in Nuremberg (Germany); the same tendency also occurred in the United States (de Planhol 2004). However, quantitative data on pigeon numbers were not always available and led to frightening speculations. 
For instance, during a city council meeting in Paris in 1969, the pigeon population was estimated to be one million (Bulletin Officiel Municipal de la ville de Paris 1969) without any census (Baud and Brugère 1995); this estimation has since proven to have been excessively exaggerated (Vacher 1970).

Claims about the nuisance caused by pigeon droppings in cities began to be expressed as early as the 1930s and 1940s in journal articles in Europe and overseas (Givois, unpublished data; Jerolmack 2008). Complaints that pigeon feces were dirtying and harming historical buildings and monuments became common in French newspaper articles in the following decade (Givois, unpublished data). The ambiguous discourse between the promotion of pigeon breeding on the one hand and the critics on the other hand reveals the growing division occurring between captive domestic pigeons and feral urban pigeons. However, no public measures against pigeons were undertaken before the 1950s, most likely because of their status as a human auxiliary: it was previously a criminal offense to harm pigeons as they could be someone's property (Renauldon 1765; Charriaut 1870). However, in 1955, urban pigeons were legally declared res nullius, that is, ownerless, belonging neither to the city of Paris nor to any local authority (Bulletin Officiel Municipal de la ville de Paris 1955). Public opinion regarding pigeons encountered a turning point when they became associated not only with overcrowding, defecating and dirtying monuments, statues and buildings but also with carrying viruses and diseases. In particular, the discovery of the bacterium Chlamydia psittaci (Eb 1993), which can potentially cause pulmonary problems, was relayed by a 1952 article that claimed that $70 \%$ of pigeons in Paris were carrying the disease (Lépine 1952). These scientific data raised debates about pigeons as a threat to humans, comparing pigeons to 'rats with wings' (Jerolmack 2008).

In France, feeding of urban pigeons in the outer realm became prohibited by law in 1966 (Vacher 1970), more or less at the same period as in other Western cities. At the same time, urban pigeon populations started to be controlled by trapping, poisoning, shooting, gassing, and so on (Haag-Wackernagel, 2002; Jerolmack 2008).

These anti-pigeon measures occurred during the emergence of a wide-reaching, hygienist conception of the modern city in the twentieth century in Europe and the United States (Hodak 1999; Leblanc 2003), that is, 'orderly and sanitized, with nature subdued and compartmentalized' (Jerolmack 2008:72). This hygienism was explained as a reaction to the massive arrival of animals and to ever-growing cities with proportionately increased city dweller requirements in terms of consumption of animal products at the end of the nineteenth century. Entire herds of animals were brought to the city daily, crammed together in the streets, to be slaughtered and quartered, often in open sheds. The exhibition of bloody carcasses on the butchers' façades; the boom of tanneries; the multiplication of horses, dogs, and cats, and thus, the omnipresence of manure, excrement, and urine; the development of maggots; smells of industrial processing of animal products; and the violent sight of animal mistreatment resulted in the creation and intensification of an olfactory and sonic world (Baratay 2009). The unceasing coming and going of animals provoked chaotic traffic, especially on market days, and exhausted animals and hastily trained drivers caused increasingly more incidents. Poultry and rabbits were raised in humble families' households, whereas cows and goats, which were kept in the numerous urban barns, wandered around daily to provide people with fresh milk (Baratay, 2009). Complaints, increased conflicts between animal users and others in their neighborhood, as well as growing attention to sanitary and hygienist concerns forced municipalities to intervene (Baratay, 1998). Programs of urban renovation were launched at the end of the nineteenth century, which cleaned up the city and pushed slaughterhouses to the fringes. This redevelopment of the urban landscape not only included larger streets and squares but also vegetation, instead of animals, as a structuring element of urban space, as well in an aesthetic aim to clean up the air (Leblanc 2003).

In parallel, pigeons held no more functional utility in the beginning of the twentieth century, after their breeding was, to a great extent, abandoned. Pigeon fertilizer was supplanted by the expansion of chemical fertilizer, which began at the end of the nineteenth century (Déhérain 1892; Lagrue 1897) and increased after World War II with the modernization and the development of large-scale agriculture (Prévost 2006). The annual delivery of pigeon meat decreased in France from 209 to 67 tons between 1973 and 1979, in favor of the extensively grown chicken, because larger fillets were requested (Royer 1983). The use of pigeons as army messengers also became obsolete after the end of World War II. Pigeons did not even have a function as a moral guide when the Christian religion progressively abandoned its symbolic bestiary from 1930 to 1950 as a consequence of its internal evolution. Animals have indeed been stripped of their religious functions in an attempt to break with rural connotations and to humanize, rationalize and adapt religion to urban life (Baratay 1994).

However, new behavioral particularities observed in urban pigeons could have induced the erosion of their former moral function. First, as with other Columbidae, pigeons feed their young with crop milk and they can reproduce throughout the year as soon as adults can obtain enough food (Johnston and Janiga 1995). Thus, urban pigeons can reproduce throughout the year (with 
lower reproduction in winter, Jacquin et al. 2010), which led to them becoming a symbol of hypersexuality and debauchery rather than chastity or other moral values, in a secular society. Second, the alimentary behavior of urban pigeons changed from seed-eating behavior to an omnivorous diet (Johnston and Janiga 1995): although they originally fed on seeds found in the fields (Richelet 1680; Diderot and D'Alembert 1751), they switched to foraging on society's waste in the urban context. By continuously walking on the city ground, pigeons stand in opposition to the upstroke of birds and so have broken their symbol of elevation. In a French doctoral thesis in 1970, they were even labeled as 'pigeons de sol', literally 'ground pigeons' (Vacher 1970). As scavengers, pigeons became the incarnation of the ordinary, if not mediocrity, in contradiction to their supernatural aspect (bright whiteness, extraordinary behavior, and sudden appearance) and their higher condition in religious imaginary.

\section{Discussion}

\section{(De)domestication: the (un)structuring principle}

The redefinition of pigeons as a nuisance species is historically related to discourses about hygiene and the dirtiness of pigeons. Referring to Douglas' definition of dirt as 'matter out of place', there is no absolute dirt and, 'Eliminating it is not a negative movement, but a positive effort to organize the environment', (Douglas 1966:2). We propose that pigeons' dirtiness was related to the broader social dynamic of the redefinition of space underlying the emergence of the hygienic city. By delineating the spaces allocated to animals and those reserved to human beings, these so-called 'imaginative geographies of animals' (Philo and Wilbert 2000:11) determine the acceptance or discomfort and rejection when animals transgress the lines imposed on them and therefore become constructed as nuisance animals (Jerolmack 2008). Following this proposition, pigeons were deemed as disturbing and polluting because they were considered not in their right place. Spatial relations between animals and society are thus decisive for the human interpretation of animal and pigeon representations as nuisances and, in this regard, are grounded on a deeper 'cultural and spatial logic' (Jerolmack 2008:72).

What is crucial here is that this spatialization, that is, what is or is not the appropriate place for animals, depends on the animal's status, defined by religious, public, legal, or scientific authorities, based on the contemporary cultural categorizations of animals (Vourc'h and Pelosse 1993). In Western societies, animals are mostly categorized as either "wild" or "domestic". In France, the deep roots of this classification can be traced back to the seventh century $\mathrm{CE}$ with the encyclopedists Isidore de Séville (Etymologies, in Voisenet 2000) and Raban Maur (De Natura rerum 842-847, in Voisenet
2000). They were consolidated thereafter over centuries in encyclopedias and treatises of natural history (Vourc'h and Pelosse 1993), including the famous zoologist Buffon in the eighteenth century who rejected the nomenclature of animals following morphological criteria elaborated by Linneus at that time (Vourc'h and Pelosse 1993). Urban pigeons, however, do not belong to any of these categories; they are 'in between'. Indeed, as they went through domestication, urban pigeons differ from their wild ancestors, the rock dove Columba livia, with respect to their genetic and behavioral characteristics (Sol 2008). This is common among all domesticated species. The problem in urban pigeons is that because they are living ferally, settling, feeding, and mating freely, they are no longer domesticated (de Planhol 2004). In France, this was reflected in their lack of legal status. Laws on wild animals apply to specific legal classifications of 'wild' animals, protected species, species that can be hunted, and so on, whereas laws on 'domestic' animals apply only through ownership (Vacher 1970).

Therefore, we argue that the reason for pigeons being out of place is that they belong to none of the common Western animal categories; more precisely, they no longer fit their former domesticate category. Hence, dirt and hygiene issues, as well as the perceived disturbance of pigeons, were grounded more deeply in their contesting of their domesticated status. However, what is at stake in this 'de-domestication'?

Anthropological studies have revealed that the wilddomestic distinction is not a universal organizing principal (O’Rourke 2000; Descola 2004). Indeed, domestication involves not only biological (Driscoll et al. 2009) but also cultural components (Russel 2002), from the production and use of animals to social organization and systems of representation (Digard 1988). Anthropological studies have provided valuable examples of the conceptions of hunter-gatherer and nomadic pastoral societies' regarding the species and spaces they use, transform, and live with, revealing that the wild-domestic distinction is not a universal organizing principal (O’Rourke 2000; Descola 2004). Even where these categories do exist, the domestic, the wild in general, and domestic and wild animals in particular hold different connotations according to cultures and contexts. Although we acknowledge the wilddomestic dichotomy as a cultural construction, we will rely on it here as an anthropological category because it retains an analytical utility (Russel 2002; Orton 2010; Micoud 2010). The goal hence is not to provide a valid definition of domestication but rather to examine the representations related to it. Domestication is commonly recognized as difficult to define due to the variety of situations that cannot be neatly classified as wild or domestic. From a biological perspective, a domestic animal differs from its wild origin 'by its genetic composition 
and hereditary phenotype characteristics, including morphology and behavior, resulting from a long and deliberate human induced selective breeding' (O’Rourke 2000: 149); a domestic animal 'has [also] been bred in captivity, for purposes of subsistence or profit, in a human community that maintains complete mastery over its breeding, organization of territory, and food supply' (CluttonBrock 1994: 26). From a socio-anthropological perspective, domestication 'can be said to exist when living animals are integrated as objects into the socio-economic organization of the human group, in the sense that, while living, those animals are objects for ownership, inheritance, exchange, trade', (Ducos 1978: 54). Indeed, the term 'domestic' itself comes from the Latin term domesticus and literally means 'of the house' (domus, the house); it clearly denotes the act of making private (Digard 1990). Moreover, domestic animals are legally defined in French law as having a master (O’Rourke, 2000).

Both biological and socio-anthropological approaches share the aspect of human mastery on and use of domestic animal as resources: control exerted on movement and breeding, converting animals into property and goods as a food supply, product for industrial use, energy and labor force, and territory and herd defense (Delort 1984). The utilitarian aspect of domestication has expanded since the eighteenth century (Baratay 2009). Demographic and economic growth, together with industrialization and urbanization, strengthened the existing uses of domestic animals and brought new ones. The Industrial and Agricultural Revolutions increased the need for raw materials and a labor force to pull new machines, harvesters, and wagons. In addition, the boom of the textile industry exacerbated the demand for wool. Meat consumption was multiplied in some French cities by seven during the nineteenth century, together with the consumption of animal by-products. The number of soap, oil, candle, leather, fertilizer, and perfume factories that used animal skin, bones, fat, and tendons increased considerably during that period (Baratay 2009). Considering domesticated animals mainly in utilitarian terms is even mirrored in the indifference of zoological sciences to the study of domesticated animals, which was relegated to disciplines such as veterinary medicine and zootechnics (the technology of animal husbandry) that were concerned with the improvement of animals to fulfill human needs (Digard 1992).

It was precisely these aspects of control and use that were lost when pigeons became feral. The alarmism regarding the number of pigeons could therefore be discussed in relation to the latent anxiety and public fear of the undominated presence of pigeons and thus a loss of control over pigeon reproduction and spread. At the same time, pigeons held neither functional utility, owing to the transformation and intensification of agriculture and the evolution of communication means, nor moral value with religion's modernization as well as the development of new behavioral traits of city-dwelling pigeons. Not only did they offer no more use for society but, as the ultimate 'provocation', urban pigeons started to use society by eating and living on human refuse. The French term for 'feral', marrons, is in this context particularly telling, as it has been taken over by an analogy to the pejorative designation of runaway slaves (Digard 1990). It is compelling that the loss of the former use and subordination was taken as the principal element to designate and define feral individuals with a negative connotation.

Given this historical and ecological framework, we propose that the understanding of pigeons as pests resulted from the dialectical relationship between changing social processes and pigeons' own agency in terms of ecological and behavioral traits. Hygiene issues were revealed to be a question of boundaries and space allocated to animals related to their status. In fact, the current representation of pigeons as disturbing reflects the underlying discomfort with animals that no longer comply with human control and no longer show utility to society. In other words, we argue that the socionature of pigeons was produced in a human-animal network ordered by control and utilitarian relations of the first towards the latter. As pigeons went against the system rules, they became constructed as a nuisance species.

\section{The dominant anthropocentric paradigm}

The structuration of the network has to be considered in the light of the nexus of power relations and dominant interests (Heynen 2006, Blaikie 1999). In light of Western ideas, it appears that the understanding of animals as subordinate and at service to human beings is a normative scheme relying on a dominant anthropocentric paradigm, which has been built and constantly renewed over time by the religious, intellectual, scientific, and public authorities, who had the cultural monopoly and the power to impose their schemes (Breakwell 1993).

In Western culture, the Judeo-Christian tradition is of particular importance to understanding the shaping and evolution of thoughts (Baratay 2010). In particular, the Old Testament is the basis of a representation of animals as being subdued and serving human beings (Delort 1984). In the biblical narrative of Genesis, Man, who was already made in God's image, is constituted king on earth and the master who received power over nature from God (Baratay 1995, Genesis 1:26). Even after the Fall, where Adam and his descendants lost their initial power over animals, it is restituted after the Flood: 'Everything that lives and moves about will be food for 
you. Just as I gave you the green plants, I now give you everything (Genesis 9:3).'

Beyond the established dualism of man and nature, it was presented as God's will that human beings should exploit nature and that everything in the physical Creation exists to serve their purposes (White 1967). However, feral animals go against the anthropo-finality of Creation. To take up the religious imagery, it is as if animals, through their feral state, would make humans go through the Fall again.

The necessary connection between human dominion over animals with spiritual and symbolic human thought has already been highlighted as lying at the origins of animal domestication. Aside from "pet keeping", animal appropriation (that is, domination) is almost impossible in animist or totemic societies as in their 'horizontal', cosmogonic conception of the world they consider animals, plants and humans as existing within the same hierarchical level. In sharp contrast, to start the process of animal domestication [...] humans had to radically change their "horizontal" conception of the world into a "vertical" one. Humans were beginning to see themselves within a hierarchical order dominated by divinities, placing themselves above animals and plants, which in turn allowed them to dominate or even kill them', (Vigne 2011: 178).

The idea that animals were created with an anthropocentric finality has been transmitted through theology over the centuries. In the eighteenth century, Protestant and Catholic discourses affirmed that the horse had been created to carry human beings, sheep to provide them with wool, dogs as company, and so on. As Baratay (1998) observed, this was more than a unidirectional influence, but rather a continuous interaction between religion and society, with the latter using the former as justification for its customs.

These Judeo-Christian representations have been relayed using different authoritative currents of thought through scientific and philosophical justifications for animal subordination and use. In classical rationalism in the seventeenth century and in Descartes' influential thesis of animals as machines, human rationality allowed human beings to emerge from the irrational, instinct-driven animal world. Conversely, animals were determined by inherited biological laws. In this dualist world view, human beings, who are endowed with reason and self-awareness, have transcended nature; they thus have prerogative over the mechanic driven animals (O'Rourke 2000). This theory allows for the limitless use of animals at a time when Western science was beginning to achieve World dominion and was attempting, scientifically and philosophically, to demonstrate man's central position in Creation (Baratay 1995). Similarly, a key tenet of scholars of the Western Enlightenment, including Kant and Bacon, was also to affirm human separation from nature and its necessary mastery over nature (Van der Born 2007, Smith 2006). In much the same way, two centuries later, in the nineteenth century, the naturalist Geoffroy Saint-Hilaire defined the history of domestication as that of the development of human power, through which human beings became dominant over the other species and would have added supplementary ones to those appearing at the Creation (Saint-Hilaire 1836). Though Darwin and other naturalists challenged the notion of the divine plan of the Creation, hierarchical patterns remained unchanged. Human beings might be animals, but only they possess rationality, language, consciousness, or emotions, which justified and also explained in terms of evolution their perceptions of inferiority and superiority (Mullin 1999, O'Rourke 2000). At the same time, in 1850, French legal authorities reasserted human domination over animals, when elaborating the first law for the protection of domestic animals (Loi Grammont) and selecting animal usefulness for human beings as the criteria for the application of the law (Pierre 2007).

Although alternative perceptions also existed, animal representations in utilitarian and control terms remained the dominant view during the colonial era in the eighteenth and nineteenth centuries, notably through zoological gardens, which were used as a privileged laboratory in the Western undertaking to domesticate wild fauna completely and to discover potentially new uses for them (Baratay 1998). Locked behind bars, they were presented as defeated and subdued, mirroring the colonial dream of overall dominion (Digard 1988; Baratay 1997). The appropriation of the wild was a window into the colonial enterprise in general, with zoo animals being a symbol for the colonized people (Hodak 1999).

More generally, it is indeed worth noting that domestication is an archetype of other forms of subordination and utilitarianism (Thomas 1984). The control and utilitarian relations in the domestication of animals at this period provided a domination model potentially extended to human beings, with inferiority criteria based on sex, ethnic or economic distinctions (for example, women, American Indians, Africans, the poor; see, Mullin 1999).

The remaining question here is what collective interests these moral and political institutions are powerfully protecting through their normative discourses on the human-animal hierarchy.

\section{I subdue, therefore I am}

Our hypothesis is that human beings define themselves as a species precisely through their representations of utility and domination towards animals. Hence, they can define their own and unique place among, and above, the living. Representations of subdued animals can be viewed as a projection of human demarcation from and 
civilizing aspiration of their own natural state and mirror their interpretation of self as outside of animality. Because it is totally constructed by human beings, the city could be considered as the place par excellence for this self-definition.

Social representation theory (Moscovici and Hewstone 1983) conceptualizes identity as a location within representations, which would, beyond their cognitive and symbolic functions, include an identity function (Moloney 2010; Miguel et al. 2010). Sharing representations contributes to group identity formation because group members have a common 'world view' (Moscovici and Hewstone, 1983; Miguel et al. 2010). A reason driving the establishment of representations is here to assert and maintain a specific identity, as well as to valorize the group (CohenScali and Moliner, 2008). The processes of identity formation, as implied in representations (Duveen 2001, in Breakwell 1993), takes place in contradistinction to the 'others', by defining the members of the group in respect to who they are not (Moloney 2010; Andreouli 2010). Thus, defined social identities are then credited with certain rights and duties (Andreouli 2010:14.3-5). By reflecting social rules and relations, social representations function as guides for action, which legitimize and orient behaviors, and justify and influence social relations (Miguel et al. 2010:23.3). The extent to which an identity and the representations related to it are shared within a group will thus also derive from the purpose they are serving and how significant it is for the group (Breakwell 1993). We use this theory in an extended sense compared with only human-human social representations, as we include non-human beings (animals, objects, and technologies) as constitutive of the social world (sensus, Latour 1993). As social identities can, in turn, shape the development of social representations through their acceptance and use (Breakwell 1993), it is thus precisely because pigeons continuously challenge humans' definitions of themselves in relation to their utility and control towards animals and by resisting all the attempts to repel or kill them, and being, in all their uselessness and insubordination, so public, that pigeons are constructed as a nuisance species.

As public and intellectual authorities are, as we showed, essential in defining and perpetuating normative representations of proper human-animal relations, we can consider that it is precisely the Western dominant paradigm that delineates human identity specifically in its utilitarian control in relation to animals. Indeed, animal exploitation constituted a very important turning point in human history, starting with the transition from hunting and gathering to farming and food production during the Neolithic Revolution. These new human behaviors were accompanied by changes in settlement patterns, demography, social organization, or technology and allowed the development of most of what is considered human culture today (Crabtree 1993; Driscoll et al. 2009). We could, however, hypothesize further that by anchoring animal domination and use in human identity, the Western dominant paradigm makes animal exploitation an intrinsic in human identity rooted right and ensures as a consequence its social acceptance. Indeed, within a set of norms, beliefs and practices, it is much easier for everyone to adhere to the established pattern than to make changes. This dynamic can be linked to the overall externalization of nature in capitalist societies. Indeed, 'it is much easier to rationalize the profit-driven rape of earth and body alike if that nature is objectified' (Smith 2006:xiii).

\section{Conclusions}

In each historical period, pigeons were as much a vehicle for the creation and maintenance of social systems as they were a product of those systems. As soon as they stopped complying with the normative network dynamics and the dominant paradigm of valorizing or depreciating animals based on their function and subordination towards humans, they were themselves reformed as a nuisance species for the purpose of human identity construction. Through the pigeon example, we have shown that the concept of nuisance species relies on complex dynamics that, while certainly and definitely including the animals' ecological and behavioral characteristics (here, their abundance and foraging behavior in cities), also involves interactions with socio-political processes. This last aspect remains widely ignored when dealing with nuisance species in conservation issues. However, considering nuisance species as a type of socio-nature further allows turning the problem around; rather than a question of nuisance species, the current failure of the modern society to stop the biodiversity crisis despite such a high level of knowledge and power could be seen as being precisely grounded in the Western paradigm of environmental dominance and exploitation. Indeed, 'still today, terms such as "sustainable development" and "natural resource management" imply the imposition of human values on and control over living nature' (O'Rourke 2000: 147). In that case, (scientific) authorities should be conscious of and reflective on their role and impact and lastly their responsibility to the development and structure of present-day environmental stances.

\section{Competing interests}

The authors declare that they have no competing interests.

\section{Authors' contributions}

ZS carried out the literature survey and wrote the manuscript. ACPJ and SP helped to draft the manuscript. All authors read and approved the final manuscript. 


\section{Acknowledgements}

We would like to thank Professor Eric Baratay and Dr. Assaf Shwartz for helpful discussions and suggestions about this article, as well as two anonymous referees for their comments.

\section{Author details}

${ }^{1}$ Centre d'Ecologie et des Sciences de la Conservation CESCO, UMR 7204 CNRS-MNHN-UPMC, Museum National d'Histoire Naturelle, CP 51, 55 rue Buffon, F-75005 Paris, France. 'Laboratoire d'Archéozoologie et Archéobotanique, UMR 7209 CNRS-MNHN, Museum National d'Histoire Naturelle, CP 51, 55 rue Buffon, F-75005 Paris, France.

\section{Received: 15 July 2013 Accepted: 12 December 2013}

Published: 28 January 2014

\section{References}

Agosta SJ, Klemens JA (2008) Ecological fitting by phenotypically flexible genotypes: implications for species associations, community assembly, and evolution. Ecol Letters 11:1123-1134

Allys (1909) Le Pigeon dans l'Egypte Ancienne. La Correspondance d'Orient 12/1909:1053-1054

Andreouli E (2010) Identity, positioning and self-other relations. Papers on Social Representations 19:14.1-14.13

Baratay E (1994) Les Controverses Contemporaines sur le Statut de l'Animal. L'Exemple de l'Eglise Catholique, France, 1940-1990. Revue d'histoire moderne et contemporaine 41(3):499-514

Baratay E (1995) Zoologie et Eglise catholique dans la France du XVIIle siècle (1670-1840): une science au service de Dieu. Revue d'histoire des sciences 48(3):241-266

Baratay E (1997) Un Instrument Symbolique de la Domestication: Le Jardin Zoologique aux XIXe-XXe Siècles (L'Exemple du Parc de la Tête d'Or à Lyon). Cahiers d'Histoire 3-4, L'animal domestique, pp 677-706

Baratay E (1998) L'Anthropocentrisme du Christianisme Occidental, In: B. Cyrulnik (ed.), Si les lions pouvaient parler. Essais sur la condition animale, Gallimard, Paris, pp 1428-1459

Baratay E (2009) Le Grand Rapprochement. L'Histoire 338:78-87

Baratay E (2010) Penser l'animal dans le catholicisme français contemporain (1940-2010). Klesis Revue philosophique - Humanité et animalité 16:201-2012

Barot A (1891) Leçons de Choses. Alcan, Paris

Baud C, Brugère H (1995) Chiens et Pigeons en Milieu Urbain: Population, Pollutions, Solutions. Thèse Méd. Vét. Alfort, Paris

Bibliothèque Nationale de France (2013) Gallica bibliothèque numérique. http:// gallica.bnf.fr/. Accessed 1 Nov 2011

Blaikie P (1999) A review of political ecology. issues, epistemology and analytical narratives. Zeitschrift für Wirtschaftsgeographie Jg 43(3-4):131-147

Blechman AD (2006) Pigeons. The fascinating saga of the world's most revered and reviled bird. Grove Press, New York

Bois M (1847) Le Nouvel Art d'Elever et de Multiplier les Pigeons. Tissot, Paris

Bonnery G (1909) Pages Oubliées, Légendes et Traditions. Monnoyer, Le Mans

Bonnier G (1922) Technologie: zoologie appliquée. Les Fils d'Emile Deyrolle Editeur, Paris

Bourguignon A (1882) Volontariat d'un An. Agriculture. Garnier Frères, Paris Breakwell GM (1993) Social representations and social identity. Papers on Social Representations 2(3):1-20

Breteuil J (1860) Le Cuisinier Européen. Garnier Frères, Paris

Brévans J (1892) Le Pain et la viande. Baillère, Paris

Bulletin Officiel Municipal de la ville de Paris (1955). Paris

Bulletin Officiel Municipal de la ville de Paris (1969). Paris

Bulletin Technique du Génie Militaire (1936). , Paris

Castree N, Braun B (2001) Social nature. Blackwell, New York

Chapin FS, III, Starfield AM (1997) Time lags and novel ecosystems in response to transient climate change in Arctic Alaska. Clim Change 35:449-461

Charriaut F (1870) Collection Générale des Lois et Décrets du Gouvernement. Gouvernement de la Défense Nationale, Paris

Clutton-Brock J (1994) The unnatural world: behavioural aspects of humans and animals in the process of domestication. In: Manning A, Serpell JA (ed) Animals and human society: changing perspectives. James Serpell, London, pp 23-35

Cohen-Scali V, Moliner P (2008) Représentations Sociales et Identité: Des Relations Complexes et Multiples. L'orientation scolaire et professionnelle 37(4):465-482

Colautti RI, Maclsaac HJ (2004) A neutral terminology to define 'invasive' species. Divers Distrib 10:135-141
Conseil Général. Rapports et Délibérations (1893) Marne Conseil Général. Rapports et Délibérations (1894) Marne Conseil Général. Rapports et Délibérations (1902) Eure Conseil Général. Rapports et Délibérations (1903) Marne Conseil Général. Rapports et Délibérations (1926) Morbihan Conseil Général. Rapports et Délibérations (1934) Marne

Corneille (1694) Pigeon. Dictionnaires des 16è et 17è Siècles. Huguet, Paris Courchamps M (1853) Dictionnaire Général de la Cuisine Française Ancienne et Moderne ainsi que de l'Office et de la Pharmacie Domestique. Plon Frères, Paris

Crabtree PJ (1993) Source early animal domestication in the Middle East and Europe. Archaeol Method Theory 5:201-245

Crespon J (1844) Faune méridionale ou Description de Tous les Animaux Vertébrés Vivans et Fossiles, Sauvages ou Domestiques [...] du Midi de la France. Editions Camariguo, Nîmes

Davis MA, Chew MK, Hobbs RJ, Lugo AE, Ewel JJ, Vermeij GJ, Brown JH, Rosenzweig ML, Gardener MR, Carroll SP, Thompson K, Pickett STA, Stromberg JC, Del Tredici P, Suding KN, Ehrenfeld JG, Grime JP, Mascaro J, Briggs JC (2011) Don't judge species on their origins. Nature 474:153-154

De Ferriere C (1741) Nouveau Commentaire sur la Coutume de la Prevoté et Vicomté de Paris. Chez Saugrin, Paris

de Planhol X (2004) Le Paysage Animal. L'Homme et la Grande Faune: Une Zoogéographie Historique. Fayard, Paris

Déhérain PP (1892) Amendements et Engrais: Engrais chimiques. In: Masson G (ed) Traité de Chimie Agricole: Développement des Végétaux, Terre Arable, Amendements et Engrais. Corbeil, Paris, pp 792-817

del Hoyo J, Elliott A, Christie D (ed) (2005) Handbook of the birds of the world vol. 10. Lynx Ediciones, Barcelona

Delort R (1984) Les Animaux ont une Histoire. Editions du Seuil, Paris

Descola P (2004) Le sauvage et le domestique. Communications 76:16-39

Diderot D, D’Alembert J-R (1751) Pigeon. Encyclopédie ou Dictionnaire Raisonné des Sciences, des Arts et des Métiers. Le Breton Editeur, Paris

Digard J-P (1988) Jalons pour une anthropologie de la domestication animale. domestication et représentations, L'Homme 108, Les Animaux, pp 27-58

Digard J-P (1990) L'Homme et les Animaux Domestiques. Anthropologie d'une Passion, Fayard, Paris

Digard JP (1992) Perspectives anthropologiques sur la relation homme-animal domestique et sur son évolution. In: Durand R (ed) L'homme, I'animal domestique et l'environnement du Moyen Âge au XVIIle siècle. Paris, pp 21-27

Douglas M (1966) Purity and danger. Penguin, London

Driscoll CA, Macdonald DW, O'Brien SJ (2009) From wild animals to domestic pets, an evolutionary view of domestication. Proc Natl Acad Sci USA 106(1):9971-9978

Ducos P (1978) Domestication defined and methodological approaches to its recognition in faunal assemblages. In: Meadow RH, Zeder MA (ed) Approaches to faunal analysis in the Middle East, Peabody Museum Bulletins No. 2. Cambridge, pp 53-56

Duveen G (2001) Representations, Identities, Resistance. In: Deaux K, Philoguène $\mathrm{G}$ (ed) Representations of the Social. Blackwell, Oxford, pp 257-270

Eb F (1993) Chlamydia psittaci: Epidémiologie, pouvoir pathogène et diagnostic. Médecine et Maladies Infectieuses 23(12):919-924

Elliott GP, Wilson PR, Taylor RH, Beggs JR (2010) Declines in common, widespread native birds in a mature temperate forest. Biol Cons 143:2119-2126

Elton C (1958) The ecology of invasions by animals and plant. Methuen, London

Falk-Peterson J, Bohn T, Sandlund OT (2006) On the numerous concepts in invasion biology. Biol Inv 8:1409-1424

Favre J (1905) Dictionnaire Universel de Cuisine Pratique. Encyclopédie Illustrée d'Hygiène Alimentaire: Modification de l'Homme par l'Alimentation. Librairie Imprimerie des Halles et de la Bourse de Commerce, Paris

Fazey I, Fazey JA, Salisbury JG, Lindenmayer DB, Dovers S (2006) The nature and role of experiential knowledge for environmental conservation. Environ Conserv 33(1):1-10

Foy F (1845) Manuel d'Hygiène. Hachette, Paris

Gayot E (1876) Le Pigeon, Histoire Naturelle, Races d'Utilité et d'Amateurs, Reproduction, Education, Hygiène, Maladies. Tomlin Press, Paris, Ecoles de Tir

Gérardin L (1905) Le Pigeon Messager dit Voyageur au XXe Siècle. O. Bornemann, Paris

Giunchi D, Baldaccini NE, Soldatini C (2007) On the use of pharmacological sterilisation to control feral pigeon populations. Wildlife Res 34:306-318

Guidez J (1969) Le Pigeon Voyageur. Bibliothèque de Travail 691:4-34

Haag-Wackernagel D (2002) Feral pigeons: management experiences in Europe, in Atti 2nd Convegno Nazionale sulla Fauna Urbana 'Specie ornitiche 
problematiche: biologia e gestiona nelle città e nel territorio', Firenze, 10 giugno 2000, ARSIA e LIPU. Firenze. M. Dinetti, Regiona Toscana, pp 25-37 Henry Y (1981) Le colombier, un Signe Extérieur de Noblesse. Essai sur les Colombiers en Bretagne. Annales de Bretagne et des pays de l'Ouest 88(1):67-86

Hermant P, Boomans D (1928) La Médecine Populaire. Bulletin du Service de Recherches Historiques et Folkloriques du Brabant, pp 43-45

Heynen N, Kaika M, Swyngedouw E (2006) Urban political ecology. Politicising the production of urban natures. In: Heynen N, Kaika M, Swyngedouw E (ed) In the nature of cities: urban political ecology and the politics of urban metabolism. Routledge, London, pp 1-19

Hodak C (1999) Les animaux dans la cité: pour une histoire urbaine de la nature Genèses 37:156-169

Hoüard D (1780) Dictionnaire analytique, historique, étymologique, critique et interprétatif de la Coutume de Normandie. Leboucher, Rouen

International Union for Conservation of Nature (2013) Invasive species. http:// www.iucn.org/about/work/programmes/species/our_work/invasive_species/. Accessed 1 Oct 2013

Jacquin L, Cazelles B, Prévot-Julliard A-C, Leboucher G, Gasparini J (2010) Reproduction management affects breeding ecology and reproduction costs in urban feral pigeons (Columba livia). Can J Zool 88:781-787

Janzen DH (1985) On ecological fitting. Oikos 45:308-310

Jerolmack C (2007) Animal archeology: domestic pigeons and the nature-culture dialectic. Qual Sociol Rev III(1):74-95

Jerolmack C (2008) How pigeons became rats: the cultural-spatial logic of problem animals. Soc Probl 55(2):72-94

Johnston RF, Janiga M (1995) Feral pigeons. Oxford University Press, Oxford

La Fontaine J (1678) Fables, Livres VII, VIII, IX, 2011th edition. Hatier, Paris

La Perre de Roo V (1877) Le Pigeon Messager, ou Guide Pour I'Elève du Pigeon Voyageur et Son Application à l'Art Militaire. Deyrolle Fils, Paris

La Ville de Mirmont H (1894) La Mythologie et les Dieux dans les Argonautiques et dans l'Enéide. Hachette, Paris

Lagrue C (1897) Engrais Chimiques. Journal de Bayeux, Sommaires de leçon de Sciences, Hygiène et Agriculture du Bessin. , Bayeux, pp 62-67

Latour B (1993) We have never been modern. Harvard University Press, Cambridge

Leblanc N (2003) La place de l'animal dans les politiques urbaines. Communications 74:159-175

Lépine P, Sauter V (1952) Sur l'infection des Pigeons Parisiens par le Virus de I'Ornithose. Bull Acad Natl Med 135:332

Lings M (1986) Le prophète Muhammad, sa Vie d'Après les Sources les Plus Anciennes. Editions du Seuil, Paris

Lowe SJ, Browne M, Boudjelas S (2000) 100 of the world's worst invasive alien species. IUCN/SSC Invasive Species Specialist Group (ISSG), Auckland, New Zealand

Lunel B (1858) Colombe. Dictionnaire universel des Connaissances Humaines. Lacroix-Comon, Paris, France

Marion L (2013) Is the Sacred ibis a real threat to biodiversity? Long-term study of its diet in non-native areas compared to native areas. C. R. Biologies: http://dx.doi.org/10.1016/j.crvi.2013.05.001

Menon (1749) La Science du Maître d'Hôtel Cuisinier, avec des Observations sur la Connaissance et Propriétés des Alimens. Paulus du Mesnil, Paris

Micoud A (2010) Sauvage ou domestique, des catégories obsolètes? Sociétés 2(108):99-107

Miguel I, Valentim J-P, Carugati F (2010) Intelligence and its development: social representations and social identities. Pap Social Representations 19:20.1-20.33

Minteer BA, Collins JP (2005) Why we need an 'ecological ethics'. Front Ecol Environ 3(6):332-337

Moloney G (2010) Articulating Social Representations and Identity through Process \& Content. Papers on Social Representations 19:15.1-15.16

Mooney HA, Mack RN, McNelly JA, Neville LE, Schei PJ, Waage JK (2005) Invasive alien species. Island Press, Washington, A new synthesis

Moquin-Tandon A (1860) Éléments de Zoologie Médicale, Contenant la Description des Animaux Utiles à la Médecine et des Espèces Nuisibles à I'Homme. Baillière, Paris

Moscovici S, Hewstone M (1983) Social representations and social explanations: from the 'Naïve' to the 'amateur' scientist. In: Hewstone M (ed) Attribution theory: social and functional extensions. Blackwell, Oxford, pp 98-125

Mullin MH (1999) Mirrors and windows: sociocultural studies of human-animal relationships. Annu Rev Anthropol 28:201-224

Nunez MA, Bailey JK, Schweitzer JA (2010) Population, community and ecosystem effect of exotic herbivores: a growing global concern. Biol Inv 12:297-301
O'Rourke E (2000) The reintroduction and reinterpretation of the wild. J Agric Environ Ethic 13:145-165

Orton D (2010) Both subject and object: herding, inalienability and sentient property in prehistory. World Archaeology 42(2):188-200

Palliez L (1932) Le Pigeon Voyageur. Son Origine, Description, ses Qualités, ses Aptitudes. Son Utilisation au Cours des Guerres Anciennes et Moderne. G. Baratte, Lille

Philo C, Wilbert C (ed) (2000) Animal spaces, beastly places. Routledge, New York

Pierre E (2007) Réformer les relations entre les hommes et les animaux: fonction et usages de la loi Grammont en France (1850-1914). Déviance et Société 1(31):65-76

Pimentel D, McNair S, Janecka J, Whitman J, Simmonds C, O'Connell C, Wong E, Russel L, Zern J, Aquino T, Tsomondo T (2001) Economic and environmental threats of alien plant, animal, and microbe invasions. Agric Ecosyst Env 84:1-20

Prevost P (2006) Les Bases de l'Agriculture. Lavoisier, Paris

Primack RB, Sarrazin F, Lecomte J (2012) Biologie de la conservation. Dunod, Paris

Renauldon J (1765) Traité historique et pratique des droits seigneuriaux. Knapen, Paris, France

Rengade J (1887) Les Besoins de la Vie et les Eléments du Bien-être, Traité Pratique de la Vie Matérielle et Morale de l'Homme. La Librairie Illustrée, Paris

Reutter L (1916) Des remèdes d'Origine Humaine et Animale Prescrits au Temps des Romains en Europe (suite et fin). Bulletin de la Société d'Histoire de la Pharmacie 13:201-204

Ribémont B (1992) Les Oiseaux Domestiques dans les encyclopédies médiévales: quelques exemples 'à la ferme'. In: Proceedings of the Symposium L'homme, l'animal domestique et l'environnement, Nantes 22-24 October 1992, R. Durand, pp 291-304

Richelet (1680) Colombe. Dictionnaires des 16è et 17è Siècles. Huguet, Paris

Robbins P (2007) Lawn people. How grasses, weeds, and chemicals made us who we are. Temple University Press, Philadelphia

Royer B (1983) Elevage du Pigeon de Chair. du Point Vétérinaire, Maisons-Alfort

Rupin E (1884) Droit de Colombier. Bulletin de la Société scientifique historique et archéologique de la Corrèze. Société Scientifique, Historique et Archéologique de la Corrèze, pp 314-321

Russell N (2002) The wild side of animal domestication. Soc Anim 10(3):285-302

Saint-Hilaire G (1836) Acclimatation et Domestication des Animaux Utiles. Entièrement Refondue et Considérablement Augmentée, 4th edition. La Maison Rustique, Paris

Salo P, Korpimäki E, Banks PB, Nordström M, Dickman CR (2006) Alien predators are more dangerous than native predators to prey populations. Proc Roy Soc B 274:1237-1243

Seastedt T, Hobbs RJ, Suding KN (2008) Management of novel ecosystems: are novel approaches required? Front Ecol Environ 6:547-553

Smith N (2006) Foreword. In: Heynen N, Kaika M, Swyngedouw E (ed) The Nature of cities: urban political ecology and the politics of urban metabolism. Routledge, London

Sol D (2008) Artificial selection, naturalization, and fitness: Darwin's pigeons revisited. Biol J Linn Soc 93:657-665

Spalikowski E (1895) Les Superstitions Médicales Normandes. Bulletins de la Société d'Anthropologie de Paris IV(6):476-478

Stuart SN, Chanson JS, Cox NA, Young BE, Rodrigues ASL, Fischman DL, Waller RW (2004) Status and trends of amphibian declines and extinctions worldwide. Science 306:1783-1786

Swyngedouw E (1999) Modernity and hybridity: nature, regeneracionismo, and the production of the Spanish Waterscape, 1890-1930. Ann Assoc Am Geogr 89(3):443-465

Swyngedowu E (2004) Social power and the urbanization of water. Oxford University Press, Oxford

Thiébaut de Berneaud A (1841) Nouveau manuel complet du cultivateur français, ou l'Art de bien cultiver les terres, de soigner les bestiaux. Roret Editeur, Paris

Thomas K (1984) Man and the Natural World. Penguin Books, Harmondsworth

Vacher M (1970) Les Pigeons de Paris. Réductions du Nombre de Pigeons dans Paris, Ses Problèmes, Essais d'un produit Chimique Inhibant la Ponte chez le Pigeon. Thesis Ecole Nationale Vétérinaire Alfort, Paris

Valéry L, Fritz C, Lefeuvre JC, Simberloff D (2008) In search of a real definition of the biological invasion phenomenon itself. Biol Inv 10:1345-1351

Valéry L, Fritz H, Lefeuvre JC, Simberloff D (2009) Invasive species can also be native. Trends Ecol Evol 24:585

Valette R (1910) Leçons de Choses. Enseignement Primaire, Classe de huitième. H. Paulin, Paris 
Van der Born RJG (2007) Thinking nature. Everyday philosophy of nature in the Netherlands. PhD thesis Radboud Universiteit Nijmegen

Van der Linden CG (1950) Le Pigeon Voyageur. Paris

Viard A (1851) Le Cuisinier National de la Ville et de la Campagne (ex-Cuisinier Royal). G. Barba, Paris

Vigne J-D (2011) The origins of animal domestication and husbandry: a major change in the history of humanity and the biosphere. Compte-Rendus Biologies 334:171-181

Voisenet J (2000) Bêtes et Hommes dans le monde médiéval. Le Bestiaire des Clercs du Ve au XIle siècle. Brepols, Turnhout

Vourc'h A, Pelosse V (1993) Du bestiaire au paysage: (Ré)introduire des espèces animales. Études rurales 129(130):51-58

Vuorisalo T, Lehikoinen E, Lahtinen R (2001) History of domestic and feral pigeons (Columba livia) in Finland before 1900 AD. Ornis Fennica 78:119-126

Wallace RL (2003) Social influences on conservation: lessons from US recovery programs for marine mammals. Conserv Biol 17:104-115

Warren CR (2007) Perspectives on the alien versus native species debate: a critique of concepts, language and practice. Progr Hum Geogr 31:427-446

White L (1967) The historical roots of our ecologic crisis. Jr. Science, New Series 155(3767):1203-1207

Wilcove DS, Rothstein D, Dubow J, Phillips A, Losos E (1998) Quantifying threats to imperiled species in the United States. Bioscience 48:607-615

doi:10.1186/2192-1709-3-3

Cite this article as: Skandrani et al: Nuisance species: beyond the ecological perspective. Ecological Processes 2014 3:3.

\section{Submit your manuscript to a SpringerOpen ${ }^{\circ}$ journal and benefit from:}

- Convenient online submission

- Rigorous peer review

- Immediate publication on acceptance

- Open access: articles freely available online

- High visibility within the field

- Retaining the copyright to your article

Submit your next manuscript at $\gg$ springeropen.com 